\title{
PELAKSANAAN PEMBELAJARAN KELOMPOK KECIL DAN PERORANGAN PADA MATA PELAJARAN BAHASA INDONESIA SISWA KELAS $X$ DI SMA NEGERI 8 KOTA BENGKULU
}

\author{
Ferny Rohmayanti, Didi Yulistio, dan Padi Utomo \\ Program Studi Pendidikan Bahasa Indonesia \\ Jurusan Pendidikan Bahasa dan Seni \\ FKIP Universitas Bengkulu \\ fernyrohmayanti28@gmail.com
}

\begin{abstract}
Abstrak
Tujuan penelitian ini mendeskripsikan proses pembelajaran kelompok kecil dan perorangan pada mata pelajaran Bahasa Indonesia siswa kelas X di SMA Negeri 8 Kota Bengkulu. Penelitian ini menggunakan metode deskriptif kualitatif. Subjek penelitian adalah guru bahasa Indonesia kelas X SMA Negeri 8 Kota Bengkulu. Teknik pengumpulan data dilakukan melalui observasi, wawancara, dan dokumentasi.Instrumen penelitian yang digunakan adalah lembar observasi.Hasil penelitian menunjukkan bahwa guru telah menerapkan keterampilan mengajar kelompok kecil dan perorangan dengan cukup baik.Pelaksanaan belajar mengajar guru harusnya lebih kreatif untuk penggunaan keterampilan kelompok kecil dan perorangan dan hendaknya terbiasa menggunakan keterampilan kelompok kecil dan perorangan dengan prosedur atau langkah-langkah yang ada pada keterampilan kelompok kecil dan perorangan.
\end{abstract}

Kata kunci: bahasa Indonesia, kelompok kecil, dan perorangan.

\begin{abstract}
The purpose of this study is to describe the learning process of small groups and individuals in the Indonesian Language subject of class X students in SMA Negeri 8 Kota Bengkulu. This study used descriptive qualitative method. The research subjects were Indonesian language teachers in class $X$ at SMA Negeri 8 Kota Bengkulu. The data collection technique is done through stages, interviews, and documentation. The research instrument used to collect data and study the behavior of small groups and individuals is behavior. The results of the study indicate that teachers have implemented small groups and individuals quite well. Lessons must be more creative for the use of small groups and individuals and their use is familiar with using small groups and individuals with or steps that exist in the skills of small groups and individuals.
\end{abstract}

Keywords: Indonesian, small groups, and individuals. 


\section{PENDAHULUAN}

Pendidikan merupakan hal yang pentingbagi kehidupan karena dengan pendidikan, seseorang dapat memiliki kecerdasan, akhlak mulia, serta keterampilan bagi dirinya. Pendidikan merupakan suatu proses dalam rangka mempengaruhi siswa agar dapat menyesuaikan diri sebaik mungkin terhadap lingkungannya (Hamalik 2012:79). Pendidikan terjadi melalui pembelajaran atau proses belajar mengajar di sekolah. Di dalam proses pembelajaran, terjadi interaksi antara guru dan peserta didik guna mencapai tujuan pembelajaran. Dalam kegiatan interaksi tersebut, pendidik atau guru bertindak mendidik peserta didik atau siswa. Tindak pendidik tersebut tertuju pada perkembangan siswa menjadi mandiri.

Profesionalisme guru dengan tugas utamanya untuk mendidik, mengajar, membimbing, mengarahkan, melatih, menilai hasil belajar peserta didik. Tugas tersebut akan tercermin pada kemahiran, kecakapan atau keterampilan seorang pendidik. Pengajaran di sekolah semakin berkembang, dimulai dari pengajaran tradisional, yang memiliki ciri-ciri tradisional konservatif berkembang menuju ke sistem pengajaran modern, yang memiliki ciri-ciri yang sesuai dengan kemajuan zaman. Dalam tahap-tahap perkembangan itu, terdapat perubahan-perubahan dalam sistem pengajaran dengan semua aspek dan unsur-unsurnya. Jadi, perkembangan pengajaran itu sejalan dengan perkembangan sekolah (Hamalik, 2012:55). Karena guru memiliki tugas utama untuk mendidik, mengajar, membimbing, mengarahkan, melatih, menilai hasil belajar peserta didik, maka seorang guru tidak hanya menguasai materi, namun juga harus dapat menguasai keterampilan dalam mengajar. Ada beberapa keterampilan mengajar dalam pembelajaran yang harus dimiliki guru, yaitu, keterampilan membuka dan menutup pelajaran, keterampilan menjelaskan, keterampilan mengadakan variasi, keterampilan memberikan penguatan, keterampilan bertanya, keterampilan mengelola kelas, keterampilan mengajar kelompok kecil dan perorangan, dan keterampilan membimbing diskusi kelompok kecil.

Berdasarkan hasil observasi pada guru kelas X SMA Negeri 8 Kota Bengkulu, menunjukkan bahwa guru masih mengalami banyak kesulitan dalam mengatasi siswa pada saat proses belajar berlangsung. Terlihat dari adanya siswa yang belum aktif dalam mengikuti proses belajar di dalam kelas baik dalam individu maupun kelompok. Oleh karena itu, berdasarkan latar belakang yang telah disampaikan tersebut, maka peneliti tertarik untuk melakukan penelitian dengan mengambil judul "Pelaksanaan Pembelajaran Kelompok Kecil dan Perorangan siswa kelas X SMA Negeri 8 Kota Bengkulu"

Pembelajaran adalah proses interaksi antara peserta didik dengan lingkungannya sehingga terjadi perubahan perilaku ke arah yang lebih baik. Dalam pembelajaran tugas guru yang paling utama adalah mengkondisikan lingkungan agar menunjang terjadinya perubahan perilaku bagi peserta didik (Kunandar, 2007:287). Pembelajaran merupakan suatu sistem, yang terdiri atas berbagai komponen yang saling berhubungan satu dengan yang lain. Komponen tersebut meliputi: tujuan, materi, metode, dan evaluasi. Keempat komponen pembelajaran tersebut harus diperhatikan oleh guru dalam memilih dan menentukan media, metode, strategi, dan pendekatan apa yang akan digunakan dalam kegiatan pembelajaran (Rusman, Kurniawan, dan Riyana, 2011:15).

Pembelajaran dapat diartikan sebagai setiap upaya yang sistematik dan sengaja untuk menciptakan agar terjadi kegiatan interaksi edukatif antara dua pihak, yaitu peserta didik (warga belajar) 
dan pendidik (sumber belajar) yang melakukan kegiatan membelajarkan (Sudjana dalam Rusman, 2011:16). Dari beberapa pendapat ahli tentang pengertian pembelajaran dapat disimpulkan pembelajaran merupakan suatu proses interaksi yang dilakukan guru dengan siswa untuk mencapai tujuan pembelajaran. Serta, dalam pelaksanaan pembelajaran tugas utama guru untuk mengkondisikan lingkungan agar terjadi perubahan perilaku pada siswa.

Keterampilan dasar yang perlu dipelajari teacher trainee: (1) keterampilan membuka dan menutup pelajaran; (2) keterampilan menjelaskan; (3) keterampilan mengadakan variasi; (4) keterampilan memberikan penguatan; (5) keterampilan bertanya; (6) keterampilan mengelola kelas; (7) keterampilan mengajar perorangan \& kelompok kecil; (8) keterampilan membimbing diskusi kelompok kecil. Keterampilan dasar tersebut harus digunakan secara tepat dalam suasana yang menyenangkan dan bergairah. Hal itu penting agar penerapan jenis keterampilan dasar mengajar dapat mencapai sasaran (Barnawi dan Arifin, 2015:128).

\section{METODE}

Metode yang digunakan dalam penelitian ini, yaitu metode deskriptif. Penelitian ini memusatkan perhatian kepada masalah-masalah aktual, sebagaimana adanya pada masa sekarang, pada saat penelitian dilakukan.

Penelitian ini dilakukan di kelas $X$ SMAN 8 Kota Bengkulu dan penelitian dilaksanakan pada 30 Januari samapai dengan 28 Februari 2017. Sumber data dari penelitian ini, yaitu guru Bahasa Indonesia kelas $X$ di SMAN 8 Kota Bengkulu dan data penelitian ini diambil pada saat proses belajar berlangsung. Dalam penelitian ini observasi bertujuan untuk mengamati pelaksanaan pembelajaran guru dalam menggunakan keterampilan kelompok kecil dan perorangan. Teknik wawancara dalam penelitian ini bertujuan untuk menggali informasi mengenai pelaksanaan pembelajaran guru dalam menggunakan keterampilan kelompok kecil dan perorangan.

Instrumen yang digunakan untuk mengambil data dalam penelitian ini adalah pedoman lembar observasi dan wawancara.data yang digunakan dalam penelitian ini yaitu menggunakan langkahlangkah: mendeskripsikan data, mengamati dan mencatat data. Data yang sudah diperoleh di lapangan setelah ditulis dalam bentuk laporan lapangan perlu dirangkum dan dipilih serta difokuskan pada halhal yang dibutuhkan. Data yang dirangkum memberi gambaran yang lebih tajam tentang hasil pengamatan, juga mempermudah peneliti untuk mencari data ulang. Mendokumentasikan data, pengambilan data dilakukan dengan mengamati, mencatat serta mendokumentasikan data sehingga data yang diperlukan bisa dapat terkumpul. Mengumpulkan dan Memverifikasi Data, pengumpulan data di lokasi penelitian dengan melakukan observasi, wawancara, dan dokumentasi dengan menentukan strategi pengumpulan data yang dipandang tepat dan untuk menentukan fokus serta pendalaman proses pendelaman data berikutnya. Menyajikan Data, Analisis dan Mempresentasikan Data, penyajian data diperlukan untuk mempermudah melihat gambaran keseluruhan atau bagian-bagian dari penelitian tersebut. Dengan demikian, peneliti dapat menguasai data dan tidak menumpuk data, sehingga sulit untuk menanganinya. Menarik Kesimpulan Data, sejak awal penelitian, peneliti harus berusaha mencari makna dari data yang dikumpulkannya. Untuk itu, peneliti harus mencari tema, hubungan, persamaan, halhal yang sering. 


\section{HASIL DAN PEMBAHASAN}

Berdasarkan hasil penelitian ada beberapa aspek yang diuraikan mengenai keterampilan pelaksanaan pembelajaran kelompok kecil dan perorangan di kelas $X$ SMAN 8 Kota Bengkulu oleh peneliti yaitu penyiapan lingkungan belajar yang terjadi dalam pelaksanaan pembelajaran kelompok kecil dan perorangan di kelas X SMAN 8 Kota Bengkulu Penyiapan lingkungan belajar ini dilakukan guru dengan cara guru selalu menjaga situasi di dalam kelas saat belajar menjadi nyaman. Di dalam kelas guru menyiapkan atau membuat aturan yang harus di taati siswa dan aturan ini juga telah disepakati oleh guru dan siswa. Aturan yang diberikan guru, yaitu terlihat jika ada siswa yang mengunyah permen atau makan di dalam kelas, hal ini dilarang.

Proses pelaksanaan pembelajaran kelompok kecil dan perorangan di kelas $X$ SMAN 8 Kota Bengkulu yaitu keterampilan mengadakan pendekatan secara pribadi Mendengarkan pada proses pembelajaran yang berlangsung menunjukan bahwa guru Bahasa Indonesia telah melaksanakan dari komponen yang ada di dalam keterampilan kelompok kecil dan perorangan yaitu mendengarkan. Guru masuk kelas seperti biasanya, sebagian siswa ada yang sudah siap di tempat duduknya msing-masing. Guru sebelum memulai proses belajar mengajar berlangsung guru mengulas sekilas materi pembelajaran sebelumnya untuk merangsang ingatan siswa. Guru menyampaikan materi atau menjelaskan materi pembelajaran kepada siswa. Guru: "Selamat pagi anak-anak, sebelum ibu memulai pelajaran hari ini, kita akan mengulas sekilas materi pelajaran sebelumnya ya?" Siswa :"lya bu." Guru:"Ayo coba siapa di antara kalian yang mau menjelaskan secara garis besarnya saja tentang materi sebelumnya." Siswa: (salah satu siswa menunjuk tangan) "Saya Bu, materi sebelumnya kita membahas mengenai struktur surat Bu." Guru: "Ya sampaikan secara garis besarnya saja ya nak?" Siswa: "Ada beberapa struktur dalam pembuatan surat yaitu kop surat, nomor surat, tanggal surat, alamat tujuan, salam pembuka, isi surat, salam penutup, tanda tangan dan nama penanggung jawab" Guru: "lya bagus jawaban dari A yang lain harus selalu ingat ya struktur dari membuat surat"

Pendekatan verbal dan nonverbal Hasil dari observasi selama pembelajaran berlangsung menunjukkan bahwa guru telah melakukan pendekatan verbal dan nonverbal. Pendekatan verbal dilakukan guru dengan cara memberikan kalimat atau kata-kata yang memberi semangat kepada siswa misalnya dengan memuji siswa. Sebagai contoh ketika siswa menyampaikan pendapatnya mengenai materi yang sedang dibahas, guru mengapresiasi dengan memberi kata-kata, Siswa: "Menurut pendapat saya $\mathrm{Bu}$, jawaban yang disampaikan kelompok $A$ akan lebih bagus jika ditambahkan dengan contoh". Guru: "Ya, bagus sekali pendapat dari teman kalian. Apakah yang lain ada yang masih mau menanggapi?" Untuk pendekatan nonverbal dilakukan guru pada saat proses belajar mengajar berlangsung. Ketika seluruh siswa melakukan diskusi biasanya ada siswa yang kurang memahami tugas apa yang akan dilakukannya, guru melakukan pendekatan nonverbal dengan berjalan mendekati siswa yang kurang memahami dan menanyakan kesulitan apa yang dihadapi oleh siswa. Guru: "Yang mana $A D$ yang belum kamu pahami tentang tugas yang ibu sampaikan? Siswa : "Ya Bu, yang belum saya pahami yang tugas terkhir Bu, apa yang tugas akhir itu juga dikasih contoh Bu" Guru: "lya nak, semua harus diberi contoh." Pendekatan verbal maupun non verbal juga tergambarkan pada saat proses belajar berlangsung. Bahwa guru dan siswa terlihat saling membangun rasa percaya antara 
guru dan siswanya. Hal ini dilakukan guru dengan cara verbal terlihat pada saat guru mempercayai salah satu siswanya untuk menyelesaikan soal. Dengan cara nonverbal, guru mendekati siswa dan menepuk bahunya dan melakukan kontak langsung dengan siswa. Guru: "Nak, sudah selesai belum tugasnya, kok malah mengobrol?" Siswa: "lya Bu, maaf tadi $A$ mengganggu saya Bu." Guru: "Lain kali jangan diulangi, ya Nak." Jadi, sesuai dengan pengamatan saat penelitian berlangsung guru menunjukkan pendekatan verbal maupun nonverbal.

Membantu tanpa mengambil alih tugas Sesuai dengan hasil pengamatan penelitian, guru membantu siswa pada saat siswa mempunyai kesulitan saat memahami materi yang disampaikan guru atau tugas yang diberikan oleh guru. Guru membantu tetapi bukan berarti guru memberitahukan jawaban atas tugas-tugas yang diberikan.

Yang dilakukan guru untuk membantu siswa menyelesaikan kesulitan siswa yang kurang memahami materi yang disampaikan adalah dengan memberikan penjelasan kembali mengenai materi yang sedang dibahas, dan juga memberikan contoh kepada siswa supaya siswa mengerti dengan materi yang disampaikan oleh guru. Dan, ketika siswa kurang paham dengan tugas yang diberikan, guru membantu menyelesaikannya dengan cara memberikan sebuah contoh mengenai tugas yang diberikan kepada siswa. Siswa: "Bu, saya ingin bertanya apakah teks ini bisa diterapkan dalam kehidupan seharihari?" Guru: "lya, pertanyaan yang bagus dan menarik sekali. Teks ini bisa kita terapkan dalam kehidupan kita sehari-hari. Ayo coba, apakah ada yang bisa memperjelas jawaban dari pertanyaan dari teman kalian?" (Salah satu siswa menunjukkan tangannya dan guru pun mempersilahkan siswa tersebut untuk menjawab.) Siswa: "Kalo menurut saya iya, karena teks ini merupakan teks negosiasi jadi bisa diterapkan dalam kehidupan sehari-hari yang mana teks nengosiasi ini kan sistemnya sama seperti dengan jual beli yang sering kita lakukan misalnya ketika berbelanja di warung ataupun di pasar yang mana ada penjual dan pembeli yang terjadi penawaran mengenai suatu barang". (Guru selalu terlihat memberi kesepatan kepada siswanya untuk lebih aktif di dalam proses pembelajaran berlangsung) Guru: "Nah, itu ada pendapat dari salah satu teman kalian apakah ada pendapat lain yang ingin disampaikan?" Siswa: (menjawab dengan serentak) "Tidak Bu...." Guru: "Baiklah kalau begitu bagaimana, apakah kalian sudah paham dengan apa yang dijelaskan teman kalian?" Siswa: (menjawab dengan serentak) "lya, paham Bu. Iya Bu apa materi ini akan masuk dalam ujian Bu?" Guru: "Iya, pastinya ya Nak, pokoknya nanti kalau Ibu kasih tahu uji Ujiannya kapan nanti ibu kasih kisi-kisinya".

Guru mendengarkan menghargai pendapat siswa, dan tidak mengabaikan semua pendapat dari siswa. Di sini guru juga terlihat mendengarkan secara simpatik pendapat atau ide yang dikemukakan oleh siswa, menerima dan merespon postif pendapat dari siswa dengan memberikan penguatan untuk lebih meningkatkan belajarnya lebih giat. Dengan ini siswa memiliki keberanian berprestasi aktif dan kreatif dalam belajar.

Menerima pendapat anak didik dan memberi rasa aman Sesuai dengan pengamatan saat penelitian berlangsung, pada saat proses belajar mengajar berlangsung guru menunjukkan bahwa siap untuk menerima perasaan atau pendapat siswa dengan penuh pengertian dan perhatian. Hal ini ditunjukkan ketika proses belajar berlangsung ada siswa yang bertanya ataupun memberikan pendapatnya guru selalu siap untuk menerima dan menanggapi semua pertnyaan dan pendapat siswa. Guru juga 
memberikan waktu yang sesuai untuk siswa menyelesaikan tugas tersebut, hal ini dilakukan guru untuk menghindari kehabisan waktu untuk menyelesaikan materi yang dibahas. Setelah siswa mengerjakan semua tugasnya guru memerintahkan siswa untuk mengumpulkan buku tugas siswa ke depan kelas. Kemudian, setelah terkumpul semua buku tugasnya guru membagikan kembali buku tugas siswa tetapi tidak kepada pemilik buku melainkan kepada siswa lainnya. Karena guru akan memerintahkan siswa untuk membacakan hasil tugas temannya. Kemudian, yang lain memberikan pendapat untuk jawaban dari temannya itu. Guru: "Ayo, anak-anak kalau sudah selesai kumpulkan tugas kalian ke depan ya, seperti biasa ya sekarang buku tugas kalian sudah terkumpul semua, ini Ibu bagikan lagi acak ya" Siswa: "Siap Bu" (siswa menjawab dengan serentak) Guru: "Sekarang dimulai dari AG bacakan hasil dari tugasnya RF nanti kita bahas bersama" Hal ini dilakukan sampai semua siswa mempunyai kesempatan untuk membacakan hasil dari tugas teman-teman mereka saling bergantian. Jawaban dari masing-masing siswa akan dibahas satu per satu. Setelah semua selesai guru akan memberikan pendapatnya atas jawaban dari siswa dan memberikan kesimpulan.

Keterampilan Mengorganisasi Kegiatan Pembelajaran. Menetapkan tujuan dan masalah Menetapkan tujuan dan masalah, pada saat proses pembelajaran guru memberitahukan atau menyampaikan terlebih dulu apa yang akan dicapai dalam setiap pembelajaran sesuai dengan materi yang akan dibahas dan guru menjelaskan apa saja tugas yang harus diselesaikan oleh para siswa untuk tugas kelompok maupun tugas individunya. Guru: "Selamat pagi anak-anak"? Siswa: "Pagi Bu." Guru: "Baiklah, sebelum kita memulai pelajaran kita, mengajak kalian untuk membahas tujuan dan masalah yang akan kita capai."
Siswa : "Baik Bu, kami akan menyiapkan alat tulis untuk mencatatnya nanti." Hal ini selalu dilakukan di setiap memulai pelajaran dengan materi yang baru atau materi yang belum dibahas.

Membagi kegiatan pembelajaran Sesuai pengamatan pada penelitian kali ini guru melakukan pembagian pembelajaran sesuai dengan kegiatan pembelajaran guru menyiapkan tempat, peralatan, dan menyampaikan prosedur atau aturanaturan yang berlaku saat kegiatan pembelajaran berlangsung. Guru : "Anakanak kegiatan kita hari ini akan kita bagi dalam tiga tahap." Siswa: "lya Bu, oya ya Bu nanti kalau tidak cukup waktunya gimana Bu?" Guru: "lya maka dari itu Nak, kita bagi dan kita atur waktunya" Siswa: "lya Bu, yang pertama kita lakukan apa Bu?" Guru: "Pertama, kita akan bahas materi pelajaran hari ini, kedua, Ibu akan membagi kalian menjadi empat kelompok, ketiga kita akan bahas hasil dari tugas kelompok kalian." Siswa: "Siap Bu" Guru juga memberikan aturan waktu yang digunakan siswa misalnya dalam mengerjakan tugas harus dengan waktu yang ditentukan.

Mengatur pembagian kelompok Dalam membagi membentuk kelompok guru terlihat menggunakan cara yang menarik, yaitu guru memberikan sebuah kertas yang telah digulung kecil kepada masing-masing siswa. Setelah semua siswa sudah mendapatkan baru guru memerintahkan kepada siswa untuk membuka kertas tersebut yang telah diberikan beberapa nama buah oleh guru. Metode ini dilakukan oleh guru agar siswa tidak jenuh ketika mengikuti pelajaran dan tidak monoton dalam pembelajaran. Guru: "Anak-anak hari ini kita akan berdiskusi ya?" Siswa : "lya Bu, diskusinya kelompok apa sama-sama Bu?" Guru: "Diskusinya Ibu akan bagi kalian menjadi empat kelompok." Siswa : "Kenapa gak pilih kelompok sendirisendiri Bu?" Guru: "Untuk saat ini tidak ya 
nak, karena kalian biar membaur sama teman yang lain." Siswa: "Terus gimana Bu bentuk kelompoknya lbu yang menentukannya?" Guru : "Nah, sekarang Ibu punya beberapa gulungan kertas, sekarang kalian ambil satu per satu ya?" Siswa : "Saya dapat tulisan nanas, saya dapat salak" (siswa saling bersautan menyebutkan nama kelompok yang mereka dapatkan) Metode ini juga bermanfaat untuk siswa agar bisa berinteraksi antar teman yang lainnya dan bersosialisasi dengan baik. Yang mana guru biasanya hanya mengatur pembagian kelompok dilakukan guru dengan cara guru membagi dalam satu kelas menjadi empat kelompok. Kemudian guru memilih salah satu siswa dari setiap kelompok untuk menjadi ketua kelompok.Tetapi, kali ini guru menggunakan metode dalam pembagian kelompok yang bisa meningkatkan pembelajaran siswa dan interaksi antarsiswa dengan baik atau dengan yang lainnya.

Mengoordinasikan kegiatan dengan cara melihat kemajuan serta penggunaan materi dan sumber Kegiatan berdiskusi juga tidak lepas dari pantauan guru. Guru selalu terlihat mengoordinir siswa untuk menjalankan atau menyelesaikan tugas kelompoknya dengan baik. Cara yang digunakan guru untuk hal ini, guru memberikan aturan untuk mengerjakan tugas kelompok yang akan didiskusikan oleh satu kelompok dan nantinya akan didiskusikan kembali dengan kelompok lainnya. Guru: "Sekarang dengarkan Ibu dulu agar kalian dapat menyelesaikan tugas kelompok yang ibu berikan". Siswa: "Iya Bu (siswa menjawab dengan serentak) Guru dalam hal ini juga tidak lepas untuk selalu mengawasi siswa pada saat mengerjakan tugas kelompok. Guru selain memberi aturan-aturan untuk mengerjakan tugas kelompok untuk siswa, juga memberikan waktu dalam mengerjakan tugasnya agar siswa selalu disiplin. Guru: "Ayo, mulai kerjakan tugas kalian karena waktu kalian mengerjakan tugas kelompok ini tidak banyak". Siswa: "lya Bu" (siswa menjawab dengan serentak) Setelah siswa sudah selesai mengerjakan tugas kelompoknya guru biasanya menyuruh salah satu siswa dari setiap masing-masing kelompok untuk membacakan atau menjelasakan hasil dari setiap kelompok.

Membagi-bagi perhatian pada berbagai tugas dan kebutuhan siswa, dan mengklasifikasikan hasil tugas Pada pengamatan terhadap guru dalam membagi perhatian dan mengklasifikasikan hasil tugas hal ini digambarkan guru dengan cara memandangi dari satu siswa ke siswa lain secara keseluruhan saat menjelaskan pelajaran agar guru selalu mengetahui kondisi kelas saat proses pembelajaran berlangsung. Selain itu, dengan cara memandang siswa diharapkan siswa merasa bahwa apa yang mereka kerjakan selalu diperhatikan oleh guru dan dihargai oleh guru. Guru juga membagi perhatian dengan cara berjalan menuju satu siswa ke siswa lain, guru menghampiri siswa yang duduk di bangkunya dan memandang secara keseluruhan terhadap siswa.

Guru juga terlihat memberi teguran dan memanggil siswa apabila ada siswa yang tidak memperhatikan saat pembelajaran berlangsung. Guru:"TR dan MA apa yang sedang kalian lakukan? Jangan mengobrol, perhatikan materi pelajaran yang ibu sampaikan." Siswa: "lya Bu tadi MA bertanya. Guru: "lya sudah sekarang selesaikan tugas kalian masingmasing." Guru juga mendatangi siswa yang sedang mengerjakan tugas yang telah diberikan. Selain itu, guru membagi perhatiannya dengan memandang seluruh siswa yang ada di kelas untuk melihat atau mengetahui kondisi dalam kelas dan berjalan dan menghampiri siswa dan menanyakan pada siswa pekerjaaannya sudah selesai apa belum. Ketika guru memberikan perhatian kepada siswa yang 
kurang mengerti mengenai materi yang dibahas guru memberikan contoh kepada siswa dengan ini siswa akan lebih mengerti dengan materi yang dibahas. Guru: "Masih ada yang belum mengerti dengan penjelasan yang sudah Ibu berikan?" Siswa: "Iya Bu, sudah mengerti." Guru: "Tidak usah malu bertanya jika memang ada yang belum kalian mengerti atau pahami." Selain mendekati siswanya ketika guru mengertahui pekerjaan siswanya telah selesai, guru meminta siswa untuk menyamapaikan hasil dari tugasnya setelah itu guru memberikan komentar dan penjelasannya supaya siswa tersebut lebih paham atau mengerti. Guru juga memberitahukan hasil pembelajaran yang telah dipelajari dan hasil tugas yang telah dikerjakan oleh siswa sudah sesuai dengan tujuan pembelajaran.

Keterampilan membimbing dan membantu. Membantu kegiatan belajar Kegiatan belajar dilaksanakan guru dan siswa dengan baik. Guru tidak hanya menjelaskan materi di depan kelas saja, melainkan guru juga berjalan mendekati siswa saat belajar. Ketika guru berjalan mendekati siswa, guru mengoreksi atau memeriksa tugas yang dikerjakan siswa.Guru : "Nak, bagian mana yang belum kamu mengerti?" Siswa: "Ini Bu, yang ini apa harus ditambah dengan saran?" (siswa sambil menunjukkan buku kepada guru). Guru: "lya dikasih saran tulis aja sarannya di bawahnya." Kegiatan yang dialakukan guru ini terlihat tidak pilih kasih atau membeda-bedakan antarsiswa yang aktif atau kurang aktif.

Guru memberi apresiasi kepada siswa. Hasil pengamatan peneliti terhadap guru untuk pemberian apresiasi dilakukan guru dalam proses belajar berlangsung yaitu terlihat ketika guru meminta siswa maju ke depan kelas dan menjawab pertanyaan dari guru memberikan apresiasinya dengan mengatakan "Bagus, beri tepuk tangan untuk teman kalian" sehingga siswa merasa diberikan penghargaan yang baik dari usahanya. Selain itu, guru menggunakan bahasa nonverbal dalam memberikan apresiasi kepada siswa, yaitu dengan gerakangerakan badan seperti memberikan anggukan, senyuman, acungan ibu jari, kadang-kadang apresiasi verbal dan non verbal dilaksankan guru bersama-sama, ketika guru memberikan apresiasi verbal "bagus" kepada seorang siswa, pada saat itu guru mengacungkan jempolnya ke arah siswa itu. Penghargaan itu terkadang diberikan oleh guru dengan memberikan sebuah permen untuk siswa yang mampu menjawab pertanyaan guru mengenai materi pelajaran yang dibahas hari ini "Siapa yang bisa mengulangi secara singkat tentang materi yang kita bahas hari ini?" Kemudian ada salah satu siswa yang mengakat tangan dan mencoba mengulang materi atau memberikan evaluasi singkat mengenai materi yang dibahas. "Ya bagus sekali evaluasi dari temanmu ini." Kemudian, guru memberikan permen sebagai penghargaan.Dengan apresiasi yang dilakukan guru tersebut siswa semakin meningkat untuk menjawab pertanyaanpertanyaan dari guru.

Guru menjadi pembimbing sekaligus fasilitator Guru menjadi pembimbing sekaligus fasilitator hal ini terlihat ketika guru menerima dan mendengar semua pendapat dari siswa dan tidak mendominasi. Guru menganggap siswa menjadi pelaku utama dalam kegiatan belajar. Guru juga sering memberikan kesempatan kepada siswa agar lebih aktif.Guru: "Sekarang dengan kelompok yang sudah Ibu pilih, Ibu harap tidak cuma satu orang yang aktif untuk menjawab pertanyaan dari teman dari kelompok lain" Siswa: "lya Bu, jadi kami bisa bagi-bagi untuk menjawab semua pertanyaan dari kelompok lain." Guru: "Iya bagus sekali ide dari teman kalian ini." Hal ini terlihat bahwa 
guru juga sabar saat proses belajar mengajar berlangsung.

Guru sebagai fasilitator yang bertugas memfasilitasi pembelajaran yang berlangsung pada diri siswa, sehingga belajar nyata dan otentik. Dengan memfasilita beberapa hal yang harus kita capai yaitu salah satunya memahmi apa itu teks eksposisi. Hal di atas menunjukkan bahwa guru membantu siswa untuk menentukan tujuan pelajaran yang akan dicapai oleh siswa agar siswa lebih mudah untuk memahami materi pelajaran dengan cepat. Pemahaman siswa terhadap materi yang dibahas juga lebih cepat.

Merecanakan kegiatan belajar Perencanaan kegiatan belajar guru menyiapkan dengan melibatkan siswanya. Hal ini dilakukan agar siswa mempunyai andil dalam perencanaan pembelajaran itu sendiri. Guru: "Anak-anak hari ini kita akan membuat rancangan kegiatan belajar kita dulu ya?" Siswa: "lya Bu, tapi apa yang harus kita lakukan Bu?" Guru: "Pertama materi kita hari ini mengenai teks eksposisi yak kan?" Siswa: "lya Bu." Guru: "Nah, sekarang kita akan membagi kelompok untuk menyelesaikan materi ini." Siswa: "Satu kelompok berapa orang Bu?" Guru: "Satu kelas bagi saja menjadi 4 kelompok sesuai dengan barisan meja kalian." Hal ini menunjukkan bahwa guru melibatkan siswa untuk perencanaan kegiatan belajar.

Mengevaluasi hasil belajar Mengevaluasi hasil belajar juga dilakukan guru dengan melibatkan siswa agar siswa juga sadar akan kemampuan yang dimiliki sudah menjadi lebih baik atau bahkan sebaliknya. Guru: "Baiklah anak-anak sebelum kita mengakhiri pelajaran kita hari ini, kita akan mengulas dengan singkat." Siswa: "Baik Bu." (siswa menjawab dengan serempak) Guru: "Siapa yang mau mengulas tentang hasil pelajaran kita hari ini?" Siswa: "Saya Bu, secara garis besarnya hasil pelajaran hari ini kita mengetahui struktur teks eksposisi dan memahaminya buk" Hal di atas menunjukkan bahwa guru memberikan kesempatan kepada siswa untuk mengevalusai hasil pelajaran yang dilakukan hari itu. Dengan hal ini siswa akan mengetahui batas pemahaman yang mereka capai.

Mengetahui evaluasi pelaksanaan pembelajaran kelompok keci dan perorangan di kelas $X$ SMAN 8 Kota Bengkulu Mengevaluasi hasil belajar, guru melakukan dengan cara mengklasifikasi hasil tugaas seperti membuat membuat laporan atau tukar pikiran dari semua siswanya. Guru juga terlihat membantu menilai hasil pencapaian dan kemajuan dari siswasiswanya.Hal ini dilakukan guru dengan memberi kesempatan kepada siswa agar siswa bisa memperbaiki diri dan hal ini juga merupakan kerjasama antara guru dengan siswa. Guru melakukan tersebut juga agar siswa terlibat karena evaluasi juga merupakan tanggung jawab siswa.

Guru biasanya mengevaluasi hasil belajar dengan memberikan sebuah tes kepada siswanya. Guru sering terlihat menggunakasn tes lisan kepada siswa. Seperti, memberikan pertanyaan kepada siswa mengenai materi yang dibahas disetiap akhir pelajaran. Guru memberikan poin bagi siswanya yang bisa menjawab pertanyaan-pertanyaan yang diajukan. Poin atau penilaian yang diberikan guru ini akan diberitahukan kepada siswa. Sehingga hal ini memacu semangat siswa untuk aktif dalam kelas.

Berdasarkan hasil analisis data penyiapan lingkungan belajar yang terjadi dalam pelaksanaan pembelajaran kelompok kecil dan perorangan di kelas X SMAN 8 Kota Bengkulu telah dilakukan guru dengan cukup baik, seperti guru menyiapkan lingkungan belajar, dengan cara guru selalu menjaga situasi di dalam kelas saat belajar menjadi nyaman sehingga siswa tidak akan terganggu untuk mengikuti proses belajar dalam kelas. 
Guru menggunakan model pembelajaran yang lebih menarik sehingga siswa lebih terlihat tertarik untuk mengikuti proses belajar dalam kelas. Meski hal ini sudah dilakukan guru dengan selalu menjaga ketertiban di dalam kelas, namun masih ada juga siswa yang terlihat membandel dengan tidak memperhatikan guru pada saat menerangkan materi, ada juga yang usil kepada teman lainnya. Hal ini sering terjadi ketika proses belajar berlangsung. Jika hal ini terjadi guru terlihat segera menegur kepada siswa yang ribut ataupun yang mengganggu temannya.

Proses pelaksanaan pembelajaran kelompok kecil dan perorangan di kelas $X$ SMAN 8 Kota Bengkulu adalah sebagai berikut: pada aspek keterampilan mengadakan pendekatan secara pribadi ini memiliki beberapa unsur yang harus dicapai oleh guru yaitu mendengarkan, dalam hal ini unsur mendengarkan telah dicapai oleh guru dan siswa. Hal ini terlihat saat proses belajar berlangsung, guru terlihat mendengarkan siswa yang berpendapat dan tidak membedakan antara siswa satu dengan yang lain. Guru memberikan kesempatan kepada siswa untuk bertanya. $\mathrm{Hal}$ ini dilakukan guru tidak hanya pada saat siswa diberikan tugas individu namun pada saat diberikan tugas kelompok guru juga melakukannya.

Guru dan siswa saling mengemukakan pendapat hal ini terjadi pada saat proses belajar berlangsung dan antara guru dan siswa terlihat saling akrab satu dengan lainnya. Pada aspek keterampilan pendekatan secara pribadi terdapat unsur pendekatan verbal dan nonverbal, pendekatan ini telah dilakukan oleh guru. Pada pendekatan verbal guru memberikan kalimat atau kata-kata yang memberikan semangat kepada siswa dan pujian juga diberikan oleh guru untuk siswa yang aktif atau bisa menjawab pertanyaan dari guru. Pendekatan verbal dan non verbal tergambar pada saat proses belajar berlangsung. Guru dan siswa membangun rasa saling percaya. Guru berjalan di kelas dan mendekati siswa yang kurang memerhatikan dengan memgang bahunya dengan perlahan dan menasehatinya.

Unsur selanjutnya membantu siswa tanpa mengambil alih tugas guru membantu siswa pada saat siswa mengalami kesulitan untuk mengerjakan tugas tersebut. Di sini guru membantu siswa tetapi bukan berarti mengerjakan tugas siswa namun guru memberikan arahan kembali kepada siswa yang belum mengerti atau belum memahami dengan tugasnya. Pada keterampilan pendekatan secara pribadi, guru menerima pendapat anak didik dan memberi rasa aman, pada saat proses belajar berlangsung guru siap menerima pendapat dan pertanyaaanpertanyaan yang diajukan oleh siswa dengan simpatik, pengertian dan perhatian.

Pemberian waktu kepada siswa untuk menyelesaikan tugas selalu dilakukan guru hal ini dilakukan guru agar siswa juga belajar disiplin dengan waktu. Keterampilan pelaksanaan kelompok kecil dan perorangan memiliki aspek keterampilan mengorganisasi. Aspek ini mempunyai beberapa unsure, yaitu unsur menetapkan tujuan dan masalah. Penetapan tujuan dan masalah dilakukan guru sebelum proses belajar belangsung dan disesuaikan dengan materi pembelajaran yang akan disampaikan oleh guru. Ha ini dilakukan guru setiap mengawali pelajaran dengan materi yang baru. Unsur selanjutnya dalam keterampilan mengorganisasi yaitu unsur membagi kegiatan belajar. Guru melakukan pembagian kegiatan belajar dengan cara sebelum memulai pelajaran guru telah menyiapkan alat, dan menyiapkan prosedur-prosedur yang berlaku saat kegiatan belajar berlangsung. Guru juga memberikan aturan waktu kepada siswa saat belajar.

Unsur mengatur pembagian kelompok, dalam unsur ini guru terlihat 
membagi kelompok dengan cara menarik, yaitu dengan cara seperti undian. Siswa mengambil gulungan kertas yang diberikan oleh guru untuk mendapatkan kelompoknya. Hal ini dilakukan guru agar siswa tidak memilih kelompoknya sendiri dengan teman yang monoton tapi siswa bisa berbaur dengan mendapat teman kelompok yang lain. Keterampilan mengorganisasi juga memiliki unsur mengatur jalannya diskusi.

Kegiatan berdiskusi selalu dalam pantauan guru. Guru selalu memantau jalanya diskusi meski telah ditentukan ketua pada masing-masing kelompok. Hal ini dilakukan guru agar siswa tepat waktu dalam mengerjakan tugasnya dan menyelesaikannya dengan baik. Pada keterampilan mengorganisasi terdapat kegiatan membagi perhatian dan mengklasifikasi hasil tugas. Guru memandangi siswa dari satu siswa kesiswa yang lainnya secara keseluruhan saat guru menjelaskan pelajaran, hal ini dilakukan guru untuk mengetahui kondisi kelas. Mamandang siswa guru berharap siswa merasa apa yang mereka kerjakan selalu diperhatikan oleh guru.

Pembagian perhatian dilakukan oleh guru dengan berjalan menuju siswa satu ke siswa lainnya, guru menghampiri siswa yang sedang asyik sendiri dan memberi teguran kepada siswa tersebut.Keterampilan membimbing dan membantu siswa ini juga aspek dari pelaksanaan kelomok kecil dan perorangan yang memiliki beberapa unsur didalamnya yaitu unsur membantu kegiatan belajar. Unsur ini hamper sama dengan unsur membantu tanpa mengambil alih tugas. Guru tidak hanya menjelaskan materi pelajaran di depan kelas, tetapi guru akan membantu siswa dengan menjelaskan secara jelas tugastugas yang akan dikerjakan oleh siswa. Guru juga akan memberikan bimbingan terlebih dulu untuk tugas yang dikerjakan secara kelompok maupun individu. Guru mendekati siswa untuk mengetahui tugas yang diberikan benar-benar dikerjakan atau tidak.

Aspek keterampilan membimbing dan membantu siswa memiliki usur selanjutnya yaitu unsur guru memberi apresiasi.Pemberian apresiasi ini dilakukan guru dalam proses belajar berlangsung, hal ini tergambar misalnya saat guru meminta siswa untuk maju ke depan kelas dan menjawab pertanyaan dari guru memberikan apresiasi dengan mengatakan "bagus, beri tepuk tangan untuk teman kalian".Unsur selanjutnya yaitu guru menjadi pembimbing sekaligus fasilitator, hal ini tergambar ketika guru menerima dan mendengar semua pendapat dari siswa dan tidak mendominasi. Guru juga memberikan fasilitas kepada siswa pada saat proses belajar berlangsung. Mengetahui evaluasi pelaksanaan pembelajaran kelompok kecil dan perorangan di kelas X SMAN 8 Kota Bengkulu Mengevaluasi hasil belajar pada penelitian guru melakukan dengan cara mengklasifikasi hasil tugaas seperti membuat laporan atau tukar pikiran dari semua siswanya. Guru juga terlihat membantu menilai hasil pencapaian dan kemajuan dari siswa-siswanya.

Hal ini dilakukan guru dengan memberi kesempatan kepada siswa agar siswa bisa memperbaiki diri dan hal ini juga merupakan kerjasama antara guru dengan siswa. Guru melakukan tersebut juga agar siswa terlibat karena evaluasi juga merupakan tanggung jawab siswa. Guru biasanya mengevaluasi hasil belajar dengan memberikan sebuah tes kepada siswanya. Guru sering terlihat menggunakasn tes lisan kepada siswa. Seperti memberikan pertanyaan kepada siswa disetiap akhir pelajaran. Guru akan memberikan poin bagi siswanya yang bisa menjawab pertanyaanpertanyaan yang diajukan. Sehingga hal ini memacu semangat siswa untuk aktif dalam kelas. Hasil dari penelitian ini menunjukkan bahwa guru menggunakan keterampilan kelompok kecil dan 
perorangan dengan disesuaikan dengan teori yang dikemukakan oleh Djamarah (2005:165) dalam mengajar kelompok kecil dan perorangan, guru bertindak sebagai operator sistem tersebut.

Dan ada empat jenis keterampilan yang diperlukan yaitu (1) keterampilan mengadakan pendekatan secara pribadi, (2) keterampilan mengorganisasi,

keterampilan membimbing dan membantu dan (4) keterampilan merencanakan dan melakukan kegiatan belajar. Namun guru belum terlihat maksimal pada saat melakukan keterampilan yang terakhir yaitu keterampilan merencanakan dan melakukan kegiatan belajar. Karena guru terlihat belum memaksimalkan untuk mengikut sertakan siswa dalam proses perencanaan dan melakukan kegiatan belajar.

\section{PENUTUP}

Kesimpulan

Dari penelitian yang telah dilakukan maka dapat disimpulkan bahwa dalam pelaksanaan pembelajaran kelompok kecil dan perorangan telah dilakukan di kelas $X$ SMA Negeri 8 Kota Bengkulu yang ditandai oleh:keterampilan mengadakan pendekatan secara pribadi,keterampilan mengorganisasi, keterampilan membimbingdan membantu, keterampilan merencanakan dan melakukan kegiatan belajar, yang secara keseluruhan menunjukkan hasil yang cukup baik.

Pelaksanaan pembelajaran

kelompok kecil dan perorangan siswa kelas $X$ pada mata pelajaran Bahasa Indonesia di SMAN 8 Kota Bengkulu dimaksud dapat dijelaskan sebagai berikut:(1) Guru telah menyiapkan lingkungan belajar, dengan cara selalu menjaga situasi di dalam kelas saat belajar. Sehingga siswa tidak terganggu untuk mengikuti proses belajar dalam kelas.

(2) Proses pelaksanaan pembelajaran kelompok kecil dan perorangan di kelas $X$ SMAN 8 Kota Bengkulu yaitu guru memulai pelajaran hal yang pertama dilakukan oleh guru menetapkan tujuan dan masalah yang akan dicapai. Pembagian kegiatan juga dilakukakn oleh guru.

Mengatur pembagian kelompok dan mengkordinasikan kegiatan belajar dengan cara melihat kemajuan siswa serta menggunakan materi dan sumber yang jelas. Pembagian perhatian juga dilakukan guru pada berbagai tugas dan kebutuuhan siswa (3) Evaluasi hasil belajar dilakukan dengan memberikan sebuah tes kepada siswa yang menggunakan tes lisan. Hal ini dilakukan guru untuk reaksi cepat tanggap siswa dalam berfikir.

\section{Saran}

Berdasarkan kesimpulan di atas maka saran yang penulis ajukan adalah sebagai berikut:Dalam pelaksanaan belajar mengajar guru harusnya lebih kreatif untuk penggunaan keterampilan kelompok kecil dan perorangan. Guru hendaknya terbiasa menggunakan keterampilan kelompok kecil dan perorangan dengan prosedur atau langkahlangkah yang ada pada keterampilan kelompok kecil dan perorangan.

\section{DAFTAR PUSTAKA}

Barnawi dan M. Arifin. 2015. Micro Teaching: Teori \& Praktik Pengajaran yang Efektif dan Kreatif. Yogyakarta : Ar-Ruzz Media.

Djamarah, Syaiful Bahri. 2005. Guru dan Anak Didik. Jakarta: PT RINEKA CIPTA.

Rusman, Deni Kurniawan dan Cepi Riana. 2011. Pembelajaran Berbasis Teknologi Informasi dan Komunikasi .Jakarta : Rajawali Pers.

Hamalik, U. 2012. Proes Belajar. Jakarta: Bumi Aksara.

Kunandar. 2007. Guru Profesional: Implementasi Kurikulum Tingkat Satuan Pendidkan. Jakarta: Rajawali Pers. 